\title{
Chlamydia psittaci in Ocular Adnexal MALT Lymphoma: a Possible Causative Agent in the Pathogenesis of This Disease
}

\author{
Maximilian C. Köller ${ }^{1} \cdot$ Ariane Aigelsreiter $^{1}$
}

Published online: 16 November 2018

(C) The Author(s) 2018

\begin{abstract}
Purpose of Review To elucidate the role and to summarize the current literature of Chlamydia psittaci $(C p)$ as a causative factor in ocular adnexal extranodal marginal B cell lymphomas (OAEMZLs).

Recent Findings The association of $C p$ and OAEMZLs varies according to geographic location. Antibiotic therapy is an effective therapeutic approach in $C p+$ OAEMZLs. $C p+$ OAEMZLs are significantly associated with chronic conjunctivitis and prolonged household animal contact. Furthermore, somatic hypermutation, intraclonal microheterogeneity, genetic aberrations, and gene promotor methylation can be found in $C p+$ OAEMZLs.

Summary It has been shown that antibiotic therapy is an effective therapeutic approach in $C p$-positive OAEMZLs, therefore raising the question if $C p$ is an important etiologic agent of this disease. Since there is evidence pointing in this direction, we summarize the recent findings and support the pathophysiological model of $C p$ as a causative agent in OAEMZLs.
\end{abstract}

Keywords Chlamydia psittaci $\cdot$ Ocular adnexa $\cdot$ MALT lymphoma $\cdot$ Pathogenesis $\cdot$ Antibiotic treatment $\cdot$ Extranodal marginal B cell lymphoma

\section{Introduction}

Lymphomas are the most frequent malignancies of the ocular adnexa. According to the Florida Cancer Registry, they make up 55\% of all orbital tumors [1]. Moreover, it has been shown that the incidence of ocular Non-Hodgkin lymphomas (NHL) among Caucasians rose steadily since 1975 up to 2001 with an annual increase of $6.2 \%$ [2]. Ocular adnexal extranodal marginal B cell lymphomas (OAEMZLs) of the MALT type make up the majority of ocular adnexal lymphomas (OAL), with percentages ranging from $36 \%$ to $89.7 \%$ of all OALs [3-11]. Taking these facts into consideration, it is of high interest to elucidate the etiology, pathogenesis, and therapeutic approaches of OAEMZL. Research suggests that infection with Chlamydia psittaci ( $C P$ ) could be one causative factor of this

This article is part of the Topical Collection on Bacteriology

Maximilian C. Köller

maximilian.koeller@stud.medunigraz.at

Ariane Aigelsreiter

Ariane.aigelsreiter@medunigraz.at

1 Diagnostic and Research Institute of Pathology, Medical University of Graz, Graz, Austria disease $[12,13 \bullet, 14,15,16 \bullet, 17,18,19 \bullet, 20,21]$ and antibiotic drugs have shown to be an effective therapeutic approach $[22-28,29 \cdot \bullet]$. Therefore, this review summarizes the most compelling current literature by proposing a pathophysiological model of $C p$ as a causative factor in OAEMZLs and discusses the therapeutic approach of antibiotic therapy in this disease.

\section{Chlamydia psittaci}

Chlamyida psittaci, broadly known as the etiologic agent of psittacosis [30], was first defined as an own species of the genus Chlamydia in 1968 by Page LA [31]. It is a gramnegative [31], obligately intracellular bacterium that can be recognized in two different forms during its life circle [32]; its extracellular infectious form called elementary body (0.2to $0.3-\mu \mathrm{m}$ diameter) and its metabolically active form the reticulate body (0.6- to 0.8 - $\mu \mathrm{m}$ diameter) [33]. During infection, chlamydial elementary bodies are attached to the host cells, and enter them via host cell-derived phagocytic vesicles. Within the host cells, the elementary bodies undergo morphological changes and transform into the larger reticulate bodies. These metabolically active forms start to divide and become 
visible as microcolonies within endosomes of the host cells, which are referred to as chlamydial inclusion. The reticulate bodies transform back into the infectious elementary bodies, after time, and the developmental cycle ends, when the Chlamydiae leave the infected host cell, either through exocytosis or lysis of the cells [32]. Feral pigeons are a regularly reported source of $C p$ infection [34], with prevalence rates of seropositivity to $C p$ antibodies in 19.4 to $95.6 \%$ of European feral pigeons [35]. Despite these facts, $C p$ infection seems to be a rare condition within the European population [36].

\section{Chlamydia psittaci as a Causative Factor of OAEMZL}

In 2004, Ferreri et al. hypothesized that $C p$ might be a causative factor for OAEMZLs [12]. This hypothesis was based on findings that suggest that extranodal marginal cell lymphomas arise from chronic inflammation due to chronic antigen stimulation [37]. As it has been shown that the presence of $C p$ is linked to chronic conjunctivitis [38]. Tissues of OAEMZL patients were screened for $C p$ by multiplex touchdown enzyme time-release polymerase chain reaction (TETR-PCR) and $C p$-DNA could be detected in $80 \%(n=40)$ of the patients' tissue samples, which was significantly higher than that in control tissues $(p<0.001)$ [12]. Since then, $C p$-DNA has been detected in OAEMZL tissue samples of various patients all over the world (Fig. 1), with frequencies ranging from 11 to $80 \%[12,13 \cdot, 14-18,19 \bullet, 20,21]$. However, there is a considerable number of reports which could not find any association of $C p$ ( $C p$-DNA in patient tissue) and OAEMZL [3, 39-48] raising the questions whether these disparities are due to different methodical approaches of $C p$-DNA detection or geographical differences. The current literature suggests that it is rather due to the latter, as Carugi et al. detected $C p$ DNA in tissue samples from Italy (Siena), whereas no $C p$ DNA was detected in tissues of OAEMZL patients from Kenya (Nairobi) using the same methodical approach [21]. Furthermore, $C p$-DNA prevalence differs significantly in tissue samples of OAEMZLs in regard to the geographic location. As $C p$-DNA prevalence was significantly higher in samples of German patients $(47 \% n=19)$ compared to samples from the UK $(12 \% n=33)$, Italy $(13 \% n=15)$, and Southern China $(11 \% n=37)(p=0.007 ; p=0.039 ; p=0.004$; respectively) [13•]. As the mere epidemiological association between $C p$ and OAEMZL is not enough to establish a causative relationship, following Koch's postulates, it has been shown that the frequencies of $C p$-DNA were significantly higher in tissues from OAEMZLs compared to controls with $p$ values ranging from $<0.001$ to $0.042[12,13 \cdot, 14]$. Moreover, $C p$ has been detected in patients with OAEMZL using different diagnostic approaches $[16 \bullet, 20,23,26]$ and $C p$ could be cultivated from conjunctival swabs and PBMCs of patients with
OAEMZL, whereby $100 \%$ of the $C p$-positive cultures originated from patients of $C p$-DNA-positive OAEMZLs [20]. In addition, $C p$ was found in a single case of a diffuse large $\mathrm{B}$ cell lymphoma (DLBCL) in a woman prior successfully treated for (and in remission for $44+$ months) $C p$-positive OAEMZL. By employing DNA sequence analysis, the authors showed that both tissue samples (OAEMZL and DLBCL) contained the same chlamydial strain and were able to identify a potential animal vector (the patient's canary) harboring the same chlamydial strain in its feces and organs [49]. However, it would be too early to conclude that $C p$-infection is indeed a causative etiological agent of OAEMZL based solely on this report. Nonetheless, it can be argued, considering the aforementioned facts, that the first and second postulates of Koch have been fulfilled. It remains unclear whether the infection of $C p$ causes OAEMZL in formerly healthy individuals since to our knowledge, no study exists which truly elucidates this question. Beside the facts stated above, the most compelling evidence that $C p$ is a causative factor of OAEMZL is the efficiency of antibiotic therapy in the treatment of OAEMZL $[22-28,29 \bullet \cdot]$. This will be further discussed in the following paragraphs.

\section{A Pathophysiological Model of Chlamydia psittaci as a Causative Agent in OAEMZL}

Extranodal marginal zone B cell lymphomas (EMZLs) in the ocular adnexa (OA) develop at an anatomical site, which is believed to be devoid of MALT tissue from birth (this has been shown for the conjunctivae) [50]. However, there are recent studies that challenge this common point of view [51, 52]. Since EMZLs are thought to develop from marginal-zone B cells, due to the similarity in morphology and immunophenotyping [53], the development of MALT-tissue seems mandatory for the pathogenesis of OAEMZL. It has been shown that lymphoma cells of patients with OAEMZL show somatic hypermutations in their $\mathrm{V}_{\mathrm{H}}$ segments [37, 54]. As this hypermutations seem to be restricted to germinal centers of lymph follicles [55] caused by antigenic stimulation [56], it can be deduced that both (germinal centers/MALT tissue and antigenic stimulation) might be necessary for the pathogenesis of OAEMZL. That gives putative evidence for the hypothesis that inflammatory processes play a considerable role in the pathogenesis of OAEMZLS. These findings are followed by the fact that ongoing mutation (intraclonal microheterogeneity) could be observed in the $\mathrm{V}_{\mathrm{H}}$ genes of OAEMZL, which might suggest that some OAEMZL are still under the influence of hypermutational mechanism [37], making chronic Ag stimulation plausible. Furthermore, the hypothesis of inflammation as a causative factor in the pathogenesis of MALT lymphoma has been extensively investigated in gastric MALT lymphoma with Helicobacter pylori as its 


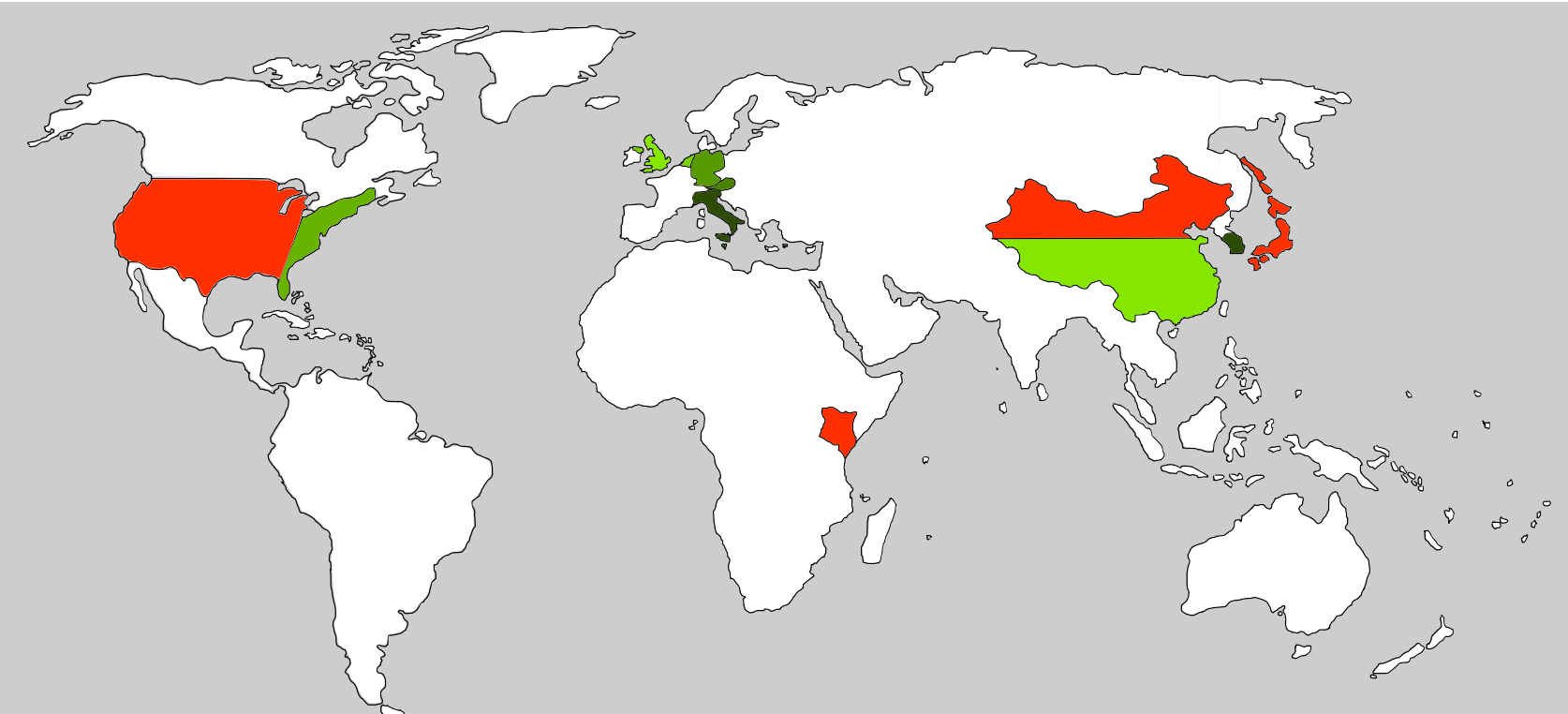

Frequence of $\mathrm{Cp}-\mathrm{DNA}$

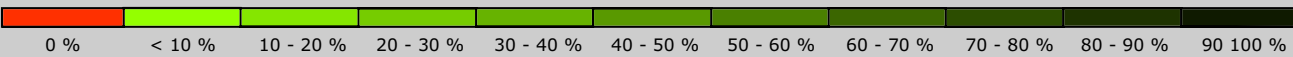

Fig. 1 Geographic differences in the detection of Chlamydia psittaci (Cp)-DNA in ocular adnexal extranodal marginal B cell lymphoma: drawing based on all Cp-positive studies $[12,13 \bullet, 14,15,16 \bullet, 17,18$, $19 \cdot, 20,21]$ as well as studies that could not find $C p$-DNA [3, 39-48]. The

etiological driving factor [57]. Considering the available evidence at that time, Suarez et al. proposed a pathophysiological model of antigen-derived marginal cell lymphomagenesis in which indirect transformation of lymphoid cells due to microbial pathogens plays one of two central hypotheses (versus direct transformation due to microbial pathogens). The model is comprised of three stages: an early phase where microbial infection, persistence, and proliferation of polyclonal Agspecific B cells takes place, followed by an antimicrobialsensitive phase where the MALT lymphoma is Ag dependent for further expansion and transformation of a B cell clone that eventually leads to an antimicrobial-insensitive phase, where the lymphoma cells are fully transformed and do not require Ag stimulation anymore [58]. In line with this model, it has been shown that:

- $\quad C p$ is associated with chronic follicular conjunctivitis [38] and patients with OAEMZL have a significantly higher prevalence of chronic conjunctivitis compared to healthy individuals $(50 \%(n=20)$ vs $5 \%(n=42) p=0.00001)$.

- The prevalence of prolonged contact with household animals (i.e., cats, birds, dogs, fishes, chickens, horses, and others) is significantly higher in OAEMZL patients $(5 \%$ $(n=20)$ vs. $0 \%(n=42) p=0.006)[20]$ as well as the multi-logistic regression odds ratio (MLR-OR) between $C p$-positive OAEMZL and non-OAEMZL OAL (i.e., lines drawn in the USA and China are arbitrary; however, the studies that found $C p$-DNA were located at the East Coast and the south, respectively. If more than one study was available in one geographic region, the highest frequency was used

nodal marginal-zone lymphoma, diffuse large B cell lymphoma, follicular lymphoma, small lymphocytic lymphoma) was significantly higher in OAEMZL OALs regarding occupational exposure to animals and slaughtering (MLR-OR (95\% CI) 7.69 (2.65-22.34) and 16.65 (3.4780.02), respectively) [59] .

- $C p$ infection can be acquired through contact with household animals (i.e., dogs [60] and birds [61]).

Taking these facts into consideration, it can be hypothesized that $C p$ serves as an etiological factor of chronic infection or recurrent infection through contact to household animals and thereby provides the possibility of chronic antigen stimulation. This is supported by the fact that somatic hypermutation and intraclonal diversity (ongoing mutation) has been found in $C p$-positive OAEMZL [62•]. Which might indicate that the lymphoma derived from $\mathrm{B}$ cell clones, which have undergone Ag selection and are still under the influence of hypermutational mechanism due to chronic Ag stimulation. However, $\mathrm{V}_{\mathrm{H}}$ genes expressed in high proportions within OAEMZL can be linked to autoreactivity [54, 63]. Raising the questions whether $C p$ serves as the antigen source itself or induces auto-immunoreactivity. This could either be through molecular mimicry, since it has been shown that Chlamydia species share immunoreactivity with eukaryotic heat shock proteins [64] or indirectly acting upon the 
malignant $\mathrm{B}$ cells, similar to what could be shown for $H p$, where the B cell receptor expressed by neoplastic B cells is directed against auto-Ags $[65,66]$ and $H p$ acts indirectly by providing an inflammatory milieu were lymphoma cells react to $H p$-specific T cells and their products instead of the bacteria [67]. Evidence that supports the latter hypothesis has been provided by Dagklis et al. who did not find a statistically significant difference in $\mathrm{V}_{\mathrm{H}^{-}}$gene usage between $C p$-positive and $C p$-negative OAEMZL nor were they able to find IGs similarities between all OAEMZL and Abs specific to Chlamydiae. However, they found that $\mathrm{V}_{\mathrm{H}^{-}} \mathrm{CDR}$ amino-acid sequence cluster analysis of three $C p$-positive OAEMZL showed homology to B cell clones in a case of rheumatoid arthritis, Sjögren's Syndrome, and a rheumatoid factor from a healthy individual immunized with mismatch red blood cells [62•]. Besides these findings, it has been shown that OAEMZL harbor $\geq 1$ genetic aberrations in $62,2 \%$ of cases [68] (Genetic aberrations found in OAEMZLs are as follows: $t(11 ; 18)(\mathrm{q} 21 ; 21)[21,68,69], t(14 ; 18)(\mathrm{q} 32, \mathrm{q} 21)[68]$, $t(3 ; 14)(\mathrm{p} 14.1 ; \mathrm{q} 32)[70]$, trisomy $3+$, and $18+[46,68,70]$, raising the question if these mutations can also be explained by a $C p$-based model. It can be hypothesized that $C p$ serves as the etiological agent of a persistent infection, thereby inducing chronic inflammation, and generating a milieu in which reactive oxygen and nitrogen species are produced by leukocytes, serving as mutagenic agents [71], similar to what has been shown for Chlamydia trachomatis infection [72]. However, evidence for $C p$ regarding this hypothesis is still lacking. Furthermore, Cargui et al. was not able to find any association between $C p$-positive OAEMZL and all FISH probes used, testing for chromosomal aberrations (i.e., BCL10, CCND1, MALT1, IGH, IGL, BCL6, BCL2, and MYC-split signal) [21]. This could be due to the very low sample size of $C p$ positive OAEMZL $(n=4)$ limiting any statistical analysis. Nonetheless, the hypothesis of $C p$ as a direct mutagenic agent still needs to be investigated in more detail. Beside genetic aberrations, it has been shown that DNA methylation in OAEMZLs is significantly associated to $C p$ status [19, 27], with $C p$-positive OAEMZLs displaying $\mathrm{CpG}$ promotor methylations in regions of known or suspected tumor suppressor genes (DAPK, ECAD, MT1G, THBS1,RAR-beta, MGMT), out of which ECAD hypermethylation is significantly associated to $C p$ positivity $(p=0.041)$ [19]. These findings are limited since it was not investigated if these methylations result in altered gene transcription. Nevertheless, promotor $\mathrm{CpG}$ methylation of ECAD (a protein maintaining cell-to-cell contacts due to being one of the cadherin molecules) has shown to be significantly associated with gastric $H p$ infection, $(p=0.002)$ as well as with depth of tumor invasion $(p=0.02)$ and regional nodal metastasis $(p=0.05)$ in gastric cancer [73]. Furthermore, the decrease of ECAD was found to be correlated to malignant transformation from chronic gastritis, to chronic atrophic gastritis, intestinal metaplasia, up to gastric cancer and further to lymph node metastasis (i.e., Spearman's rho $r=-0.81,(p<0.0001))$ [74]. Moreover, Hp-eradication therapy could reverse ECAD methylation in patients with chronic gastritis [75]. These facts indicate that ECAD gene promotor methylation is an early event in cancer development, which is initiated by microbial infection and can be reversed by antimicrobial therapy (i.e., gastric cancer, $H p$ infection, $H p$-eradication therapy). Given this evidence, it might be possible that ECAD gene promotor methylation in $C p$-positive OAEMZLs has a similar role in the development of OAEMZLs, from which can be hypothesized that chronic $C p$ infection serves as a causative agent in the initial development of OAEMZLs, and that its progression relies on continuous stimulation by $C p$ either through the bacterium itself or the inflammatory microenvironment it provides. Evidence that strengthens this hypothesis is that $C p$ infection has been shown to be significantly associated with early-stage disease $(p=0.035)$ [19], as well as the efficiency of antibiotics in the treatment of OAEMZL [22-28], which will be discussed in the following paragraph.

\section{Antibiotic Therapy in Cp-Positive OAEMZLs}

The use of antibiotic therapy in patients with $C p$-positive OAEMZL has been evaluated in several studies [22-27], since Ferreri et al. first described its effectiveness (complete remission in $71.4 \%$ of treated cases $(n=7))$ in 2004 [12]. These studies showed overall response rates ranging from 33 to $65 \%$ [22-28]. However, only three studies assessed the response to antibiotic therapy stratified to $C p$-positive and $C p$-negative cases $[23,25,26]$. Only one study could show an improved response rate for $C p$-positive OAEMZL ( $86 \%$ vs $47 \% ; p=0.02(n=34))$ [25], whereas the other studies failed to detect a statistically significant difference $(p=1.000(n=36)[26] ; p=0.25(n=27)$ [23]), even after stratifying for complete remission $p=0.18$ [23]. Interestingly, also patients suffering from $C p$-negative OAEMZL did benefit from an antibiotic therapy with response rates ranging from 38 to $60 \%[23,25,26]$. This could be due to eradication of other unknown microbes or via direct antitumor activity which has been shown for clarithromycin in animal models [76]. Possible evidence for the later hypothesis could be shown in two trials in which relapsed or refractory EMZLs were treated with clarithromycin (over all response ranging from 38 to $52 \%$ (95\% CI, 12-64\% and 32-72\%) [28, 29・•]. The authors concluded that the observed regression was rather due to a direct antitumor or immunomodulatory effect of clarithromycin than bacterial eradication since there was no evidence of bacterial infection at the time of study entry and antibiotic therapy received prior to enrollment was either refractory or a relapse occurred $[28,29 \bullet \bullet]$. However, a 
retrospective study evaluating the benefit of antibiotic therapy (doxycycline) regardless of the $C p$ status could not show any effect of lymphoma regression whatsoever [77], thus leaving the question unanswered whether antibiotic therapy should be used in patients regardless of their $C p$ status. Nevertheless, treatment with doxycycline [22-28, $29 \cdot \bullet]$ or clarithromycin $[28,29 \bullet \bullet]$ has been shown to be an effective treatment for OAEMZL, especially in $C p$-positive cases [25], and can therefore be seen as an optional therapeutic approach for patients with $C p$-positive OAEMZL.

\section{Conclusion}

Based upon the aforementioned evidence, we propose a similar model as Suarez et al. [58] regarding the pathogenesis of OAEMZL that comprises four phases:

1. $C p$ infection takes place establishing an inflammatory microenvironment in which specific $\mathrm{Ag}$ selection to either $C p$ or auto-antigens occurs leading to the proliferation and somatic hypermutation of specific polyclonal B cells.

2. This is followed by a phase of persistent or recurrent infection (due to exogenic factors, e.g., animals) that leads to neoplastic transformations, either due to mutagenic agents (e.g., ROS), epigenetic changes (e.g., promoter methylation), or both.

3. These changes in a monoclonal Ag-specific B cell lead to increased proliferation and the overgrowth of other Agspecific B cells but the $C p$-induced microenvironment is still mandatory to proliferate substantially.

4. One monoclonal Ag-specific B cell acquires further oncogenic mutations that lead to $C p$ - and Ag-independent proliferation.

However, further pathophysiological studies and prospective multi-centered clinical trials are needed to validate this model and elucidate the question whether all patients with OAEMZL should receive antibiotic therapy regardless of their $C p$ status or not.

Acknowledgements Open access funding provided by Medical University of Graz.

\section{Compliance with Ethical Standards}

Conflict of Interest The authors declare that they have no conflicts of interest.

Open Access This article is distributed under the terms of the Creative Commons Attribution 4.0 International License (http:// creativecommons.org/licenses/by/4.0/), which permits unrestricted use, distribution, and reproduction in any medium, provided you give appropriate credit to the original author(s) and the source, provide a link to the Creative Commons license, and indicate if changes were made.

\section{References}

Papers of particular interest, published recently, have been highlighted as:

- Of importance

- Of major importance

1. Margo CE, Mulla ZD. Malignant tumors of the orbit: Analysis of the Florida cancer registry. Ophthalmology. 1998;105(1):185-90.

2. Moslehi R, Devesa SS, Schairer C, Fraumeni JFJ. Rapidly increasing incidence of ocular non-hodgkin lymphoma. J Natl Cancer Inst. 2006;98(13):936-9.

3. Rosado MF, Byrne GEJ, Ding F, Fields KA, Ruiz P, Dubovy SR, et al. Ocular adnexal lymphoma: a clinicopathologic study of a large cohort of patients with no evidence for an association with Chlamydia psittaci. Blood. 2006;107(2):467-72.

4. Coupland SE, Krause L, Delecluse HJ, Anagnostopoulos I, Foss HD, Hummel M, et al. Lymphoproliferative lesions of the ocular adnexa. Analysis of 112 cases. Ophthalmology. 1998;105(8):1430 41.

5. Nakata M, Matsuno Y, Katsumata N, Takenaka T, Kobayashi Y, Narabayashi M, et al. Histology according to the Revised European-American Lymphoma Classification significantly predicts the prognosis of ocular adnexal lymphoma. Leuk Lymphoma. 1999;32(5-6):533-43.

6. Jenkins C, Rose GE, Bunce C, Wright JE, Cree IA, Plowman N, et al. Histological features of ocular adnexal lymphoma (REAL classification) and their association with patient morbidity and survival. Br J Ophthalmol. 2000;84(8):907-13.

7. Cho EY, Han JJ, Ree HJ, Ko YH, Kang YK, Ahn HS, et al. Clinicopathologic analysis of ocular adnexal lymphomas: Extranodal marginal zone B cell lymphoma constitutes the vast majority of ocular lymphomas among Koreans and affects younger patients. Am J Hematol. 2003;73(2):87-96.

8. McKelvie PA, McNab A, Francis IC, Fox R, O'Day J. Ocular adnexal lymphoproliferative disease: a series of 73 cases. Clin Exp Ophthalmol. 2001;29(6):387-93.

9. White WL, Ferry JA, Harris NL, Grove AS. Ocular adnexal lymphoma. A clinicopathologic study with identification of lymphomas of mucosa-associated lymphoid tissue type. Ophthalmology. 1995;102(12):1994-2006.

10. Ferry JA, Fung CY, Zukerberg L, Lucarelli MJ, Hasserjian RP, Preffer FI, et al. Lymphoma of the ocular adnexa: a study of 353 cases. Am J Surg Pathol. 2007;31(2):170-84.

11. Meunier J, Lumbroso-Le Rouic L, Vincent-Salomon A, Dendale R, Asselain B, Arnaud P, et al. Ophthalmologic and intraocular nonHodgkin's lymphoma: a large single centre study of initial characteristics, natural history, and prognostic factors. Hematol Oncol. 2004;22(4):143-58

12. Ferreri F, Guidoboni M, Ponzoni M, De Conciliis C, Dell'Oro S, Fleischhauer K, et al. Evidence for an association between Chlamydia psittaci and ocular adnexal lymphomas. J Natl Cancer Inst. 2004;96(8):586-94.

13. Chanudet E, Zhou Y, Bacon CM, Wotherspoon AC, MüllerHermelink H-K, Adam P, et al. Chlamydia psittaci is variably associated with ocular adnexal MALT lymphoma in different geographical regions. J Pathol. 2006;209(3):344-51. A very comprehensive study that could show that the frequency of Cp-DNA in Cp-positive OAEMZLs shows statistically significant differences according to the geographic region.

14. Yoo C, Ryu M-H, Huh J, Park JH, Kang HJ, Ahn HS, et al. Chlamydia psittaci infection and clinicopathologic analysis of ocular adnexal lymphomas in Korea. Am J Hematol. 2007;82(9):821-3. 
15. Aigelsreiter A, Leitner E, Deutsch AJA, Kessler HH, Stelzl E, Beham-Schmid C, et al. Chlamydia psittaci in MALT lymphomas of ocular adnexals: the Austrian experience. Leuk Res. 2008;32(8): 1292-4.

16. Ponzoni M, Ferreri AJM, Guidoboni M, Lettini AA, Cangi MG, Pasini E, et al. Chlamydia infection and lymphomas: Association beyond ocular adnexal lymphomas highlighted by multiple detection methods. Clin Cancer Res. 2008;14(18):5794. This study could provide compelling evidence that $\mathrm{Cp}$ is associated with OAEMZLs by using multiple detection methods.

17. Gracia E, Froesch P, Mazzucchelli L, Martin V, Rodriguez-Abreu $\mathrm{D}$, Jimenez $\mathrm{J}$, et al. Low prevalence of Chlamydia psittaci in ocular adnexal lymphomas from Cuban patients. Leuk Lymphoma. 2007;48(1):104-8.

18. Aigelsreiter A, Gerlza T, Deutsch AJA, Leitner E, Beham-Schmid C, Beham A, et al. Chlamydia psittaci Infection in nongastrointestinal extranodal MALT lymphomas and their precursor lesions. Am J Clin Pathol. 2011;135(1):70-5.

19. Choung HK, Kim YA, Lee MJ, Kim N, Khwarg SI. Multigene methylation analysis of ocular adnexal MALT lymphoma and their relationship to Chlamydophila psittaci infection and clinical characteristics in South Korea. Invest Ophthalmol Vis Sci. 2012;53(4): 1928-35. First study that could find gene promotor CpG island methylation in Cp-positive OAEMZLs and could show that Cp-positive OAEMZLs are significantly associated with the promotor hypermethylation of ECAD, a protein thought to be involved in carcinogenesis.

20. Ferreri AJM, Dolcetti R, Dognini GP, Malabarba L, Vicari N, Pasini E, et al. Chlamydophila psittaci is viable and infectious in the conjunctiva and peripheral blood of patients with ocular adnexal lymphoma: results of a single-center prospective case-control study. Int J Cancer. 2008;123(5):1089-93.

21. Carugi A, Onnis A, Antonicelli G, Rossi B, Mannucci S, Luzzi A, et al. Geographic variation and environmental conditions as cofactors in Chlamydia psittaci association with ocular adnexal lymphomas: a comparison between Italian and African samples. Hematol Oncol. 2010;28(1):20-6.

22. Ferreri AJM, Ponzoni M, Guidoboni M, De Conciliis C, Resti AG, Mazzi B, et al. Regression of ocular adnexal lymphoma after Chlamydia psittaci-eradicating antibiotic therapy. J Clin Oncol. 2005;23(22):5067-73.

23. Ferreri AJM, Ponzoni M, Guidoboni M, Resti AG, Politi LS, Cortelazzo S, et al. Bacteria-eradicating therapy with doxycycline in ocular adnexal MALT lymphoma: a multicenter prospective trial. J Natl Cancer Inst. 2006;98(19):1375-82.

24. Ferreri AJM, Dognini GP, Ponzoni M, Pecciarini L, Cangi MG, Santambrogio G, et al. Chlamydia-psittaci-eradicating antibiotic therapy in patients with advanced-stage ocular adnexal MALT lymphoma. Ann Oncol. 2008;19:194-5.

25. Ferreri AJM, Govi S, Pasini E, Mappa S, Bertoni F, Zaja F, et al. Chlamydophila psittaci eradication with doxycycline as first-line targeted therapy for ocular adnexae lymphoma: final results of an international phase II trial. J Clin Oncol. 2012;30(24):2988-94.

26. Kim TM, Kim KH, Lee MJ, Jeon YK, Lee SH, Kim DW, et al. First-line therapy with doxycycline in ocular adnexal mucosaassociated lymphoid tissue lymphoma: a retrospective analysis of clinical predictors. Cancer Sci. 2010;101(5):1199-203.

27. Lee MJ, Min B-J, Choung H-K, Kim N, Kim YA, Khwarg SI. Genome-wide DNA methylation profiles according to Chlamydophila psittaci infection and the response to doxycycline treatment in ocular adnexal lymphoma. Mol Vis. 2014;20:1037-47.

28. Govi S, Dognini GP, Licata G, Crocchiolo R, Bruno Ventre M, Assanelli A, et al. Six-month clarithromycin regimen is safe and active in extranodal Marginal zone B cell lmphomas (EMZL): a single-center phase II trial. Haematologica. 2009;94(C):147.
29.• Ferreri AJM, Sassone M, Kiesewetter B, Govi S, Scarfò L, Donadoni G, et al. High-dose clarithromycin is an active monotherapy for patients with relapsed/refractory extranodal marginal zone lymphoma of mucosa-associated lymphoid tissue (MALT): the HD-K phase II trial. Ann Oncol. 2015;26(8):1760-5. A very recent prospective clinical trial elucidating the effect of clarithromycin in the treatment of EMZLs independently to microbial eradication.

30. Ferreri AJM, Govi S, Ponzoni M. Marginal zone lymphomas and infectious agents. Semin Cancer Biol. 2013;23(6):431-40.

31. Page LA. Proposal for the recognition of two species in the genus Chlamydia Jones, Rake, and Stearns, 1945. Int J Syst Bacteriol. 1968;18(1):51-66.

32. Beatty WL, Morrison RP, Byrne GI. Persistent chlamydiae: from cell culture to a paradigm for chlamydial pathogenesis. Microbiol Rev. 1994;58(4):686-99.

33. Vanrompay D, Ducatelle R, Haesebrouck F. Chlamydia psittaci infections: a review with emphasis on avian chlamydiosis. Vet Microbiol. 1995;45(2-3):93-119.

34. Magnino S, Haag-Wackernagel D, Geigenfeind I, Helmecke S, Dovč A, Prukner-Radovčić E, et al. Chlamydial infections in feral pigeons in Europe: review of data and focus on public health implications. Vet Microbiol. 2009;135(1-2):54-67.

35. Sachse K, Kuehlewind S, Ruettger A, Schubert E, Rohde G. More than classical Chlamydia psittaci in urban pigeons. Vet Microbiol. 2012;157(3-4):476-80.

36. Koivisto AL, Isoaho R, Von Hertzen L, Toyryla M, Laippala P, Kivela SL, et al. Chlamydial antibodies in an elderly Finnish population. Scand J Infect Dis. 1999;31(2):135-9.

37. Hara Y, Nakamura N, Kuze T, Hashimoto Y, Sasaki Y, Shirakawa A, et al. Immunoglobulin heavy chain gene analysis of ocular adnexal extranodal marginal zone B-cell lymphoma. Invest Ophthalmol Vis Sci. 2001;42(11):2450-7.

38. Lietman T, Brooks D, Moncada J, Schachter J, Dawson C, Dean D. Chronic follicular conjunctivitis associated with Chlamydia psittaci or Chlamydia pneumoniae. Clin Infect Dis. 1998;26(6):1335-40.

39. Mulder MMS, Heddema ER, Pannekoek Y, Faridpooya K, Oud MECM, Schilder-Tol E, et al. No evidence for an association of ocular adnexal lymphoma with Chlamydia psittaci in a cohort of patients from the Netherlands. Leuk Res. 2006;30(10):1305-7.

40. Bahler DW, Szankasi P, Kulkarni S, Tubbs RR, Cook JR, Swerdlow $\mathrm{SH}$. Use of similar immunoglobulin VH gene segments by MALT lymphomas of the ocular adnexa. Mod Pathol. 2009;22(6):833-8.

41. Vargas RL, Fallone E, Felgar RE, Friedberg JW, Arbini AA, Andersen AA, et al. Is there an association between ocular adnexal lymphoma and infection with Chlamydia psittaci? The University of Rochester experience. Leuk Res. 2006;30(5):547-51.

42. Daibata M, Nemoto Y, Togitani K, Fukushima A, Ueno H, Ouchi $\mathrm{K}$, et al. Absence of Chlamydia psittaci in ocular adnexal lymphoma from Japanese patients. Br J Haematol. 2006;132(5):651-2.

43. Goebel N, Serr A, Mittelviefhaus H, Reinhard T, Bogdan C, AuwHaedrich C. Chlamydia psittaci, Helicobacter pylori and ocular adnexal lymphoma-is there an association? The German experience. Leuk Res. 2007;31(10):1450-2.

44. Yakushijin Y, Kodama T, Takaoka I, Tanimoto K, Bessho H, Sakai I, et al. Absence of chlamydial infection in Japanese patients with ocular adnexal lymphoma of mucosa-associated lymphoid tissue. Int J Hematol. 2007;85(3):223-30.

45. Liu Y-C, Ohyashiki JH, Ito Y, Iwaya K-I, Serizawa H, Mukai K, et al. Chlamydia psittaci in ocular adnexal lymphoma: Japanese experience. Leuk Res. 2006;30(12):1587-9.

46. Ruiz A, Reischl U, Swerdlow SH, Hartke M, Streubel B, Procop G, et al. Extranodal marginal zone B cell lymphomas of the ocular adnexa: multiparameter analysis of 34 cases including interphase molecular cytogenetics and PCR for Chlamydia psittaci. Am J Surg Pathol. 2007;31(5):792-802. 
47. Matthews JM, Moreno LI, Dennis J, Byrne GEJ, Ruiz P, Dubovy SR, et al. Ocular adnexal lymphoma: no evidence for bacterial DNA associated with lymphoma pathogenesis. Br J Haematol. 2008;142(2):246-9.

48. Zhang D, Dong L, Li H, Jin H, Ye H, Zhou X, et al. Ocular adnexal mucosa-associated lymphoid tissue lymphoma in Northern China: high frequency of numerical chromosomal changes and no evidence of an association with Chlamydia psittaci. Leuk Lymphoma. 2010;51(11):2031-8.

49. Ferreri AJM, Dolcetti R, Magnino S, Doglioni C, Cangi MG, Pecciarini L, et al. A woman and her canary: a tale of chlamydiae and lymphomas. J Natl Cancer Inst. United States. 2007;99:14189.

50. Wotherspoon AC, Hardman-Lea S, Isaacson PG. Mucosaassociated lymphoid tissue (MALT) in the human conjunctiva. J Pathol. 1994;174(1):33-7.

51. Knop E, Knop N. The role of eye-associated lymphoid tissue in corneal immune protection. J Anat. 2005;206(3):271-85.

52. Agnifili L, Mastropasqua R, Fasanella V, Di Staso S, Mastropasqua $\mathrm{A}$, Brescia L, et al. In vivo confocal microscopy of conjunctivaassociated lymphoid tissue in healthy humans. Invest Opthalmol Vis Sci. 2014;55(8):5254.

53. Harris NL, Jaffe ES, Stein H, Banks PM, Chan JK, Cleary ML, et al. A revised European-American classification of lymphoid neoplasms: a proposal from the International Lymphoma Study Group. Blood. 1994;84(5):1361-92.

54. Coupland SE, Foss HD, Anagnostopoulos I, Hummel M, Stein H. Immunoglobulin $\mathrm{VH}$ gene expression among extranodal marginal zone B cell lymphomas of the ocular adnexa. Invest Ophthalmol Vis Sci. 1999;40(3):555-62.

55. Klein U, Goossens T, Fischer M, Kanzler H, Braeuninger A, Rajewsky K, et al. Somatic hypermutation in normal and transformed human B cells. Immunol Rev. 1998;162:261-80.

56. Jacob J, Kelsoe G, Rajewsky K, Weiss U. Intraclonal generation of antibody mutants in germinal centres. Nature. 1991;354(6352): 389-92.

57. Suarez F. Infection-associated lymphomas derived from marginal zone B cells: a model of antigen-driven lymphoproliferation. Blood. 2006;107(8):3034-44.

58. Suarez F, Lortholary O, Hermine O, Lecuit M. Infection-associated lymphomas derived from marginal zone B cells: a model of antigen-driven lymphoproliferation. Blood. 2006;107(8):3034-44.

59. Dolcetti R, Serraino D, Dognini G, Govi S, Crocchiolo R, Ghia P, et al. Exposure to animals and increased risk of marginal zone Bcell lymphomas of the ocular adnexae. Br J Cancer. 2012;106(5): 966-9.

60. Sprague LD, Schubert E, Hotzel H, Scharf S, Sachse K. The detection of Chlamydophila psittaci genotype $\mathrm{C}$ infection in dogs. Vet J. 2009;181(3):274-9.

61. Telfer BL, Moberley SA, Hort KP, Branley JM, Dwyer DE, Muscatello DJ, et al. Probable psittacosis outbreak linked to wild birds. Emerg Infect Dis. 2005;11(3):391-7.

62. Dagklis A, Ponzoni M, Govi S, Cangi MG, Pasini E, Charlotte F, et al. Immunoglobulin gene repertoire in ocular adnexal lymphomas: hints on the nature of the antigenic stimulation. Leukemia. 2012;26(4):814-21. This study could show that somatic hypermutation and intraclonal microheterogeneity appears in Cp-positive OAEMZLs as well as establish evidence that linked autoimmunreactivity to $\mathrm{Cp}$-positive OAEMZLs.
63. Adam P, Haralambieva E, Hartmann M, Mao Z, Ott G, Rosenwald A. Rare occurrence of $\mathrm{IgVH}$ gene translocations and restricted IgVH gene repertoire in ocular MALT-type lymphoma. Haematologica. 2008;93(2):319-20.

64. Lamb DJ, El-Sankary W, Ferns GAA. Molecular mimicry in atherosclerosis: a role for heat shock proteins in immunisation. Atherosclerosis. 2003;167(2):177-85.

65. Hussell T, Isaacson PG, Crabtree JE, Dogan A, Spencer J. Immunoglobulin specificity of low grade B cell gastrointestinal lymphoma of mucosa-associated lymphoid tissue (MALT) type. Am J Pathol. 1993;142(1):285-92.

66. Bende RJ, Aarts WM, Riedl RG, de Jong D, Pals ST, van Noesel CJM. Among B cell non-Hodgkin's lymphomas, MALT lymphomas express a unique antibody repertoire with frequent rheumatoid factor reactivity. J Exp Med. 2005;201(8):1229-41.

67. Hussell T, Isaacson PG, Crabtree JE, Spencer J. The response of cells from low-grade B cell gastric lymphomas of mucosaassociated lymphoid tissue to Helicobacter pylori. Lancet. 1993:342(8871):571-4.

68. Streubel B, Simonitsch-Klupp I, Müllauer L, Lamprecht A, Huber $\mathrm{D}$, Siebert R, et al. Variable frequencies of MALT lymphomaassociated genetic aberrations in MALT lymphomas of different sites. Leukemia. 2004;18(10):1722-6.

69. Takada S, Yoshino T, Taniwaki M, Nakamura N, Nakamine H, Oshima $\mathrm{K}$, et al. Involvement of the chromosomal translocation $\mathrm{t}(11 ; 18)$ in some mucosa-associated lymphoid tissue lymphomas and diffuse large B-cell lymphomas of the ocular adnexa: evidence from multiplex reverse transcriptase-polymerase chain reaction and fluorescence in situ hybridization on using formalin-fixed, paraffinembedded specimens. Mod Pathol. 2003;16(5):445-52.

70. Streubel B, Vinatzer U, Lamprecht A, Raderer M, Chott A. $\mathrm{T}(3 ; 14)(\mathrm{p} 14.1 ; \mathrm{q} 32)$ involving IGH and FOXP1 is a novel recurrent chromosomal aberration in MALT lymphoma. Leukemia. 2005;19(4):652-8.

71. Coussens LM, Werb Z. Inflammation and cancer. Nature. 2002;420(6917):860-7.

72. Chumduri C, Gurumurthy RK, Zadora PK, Mi Y, Meyer TF. Chlamydia infection promotes host DNA damage and proliferation but impairs the DNA damage response. Cell Host Microbe. 2013;13(6):746-58.

73. Chan AO-O, Lam S-K, Wong BC-Y, Wong W-M, Yuen M-F, Yeung Y-H, et al. Promoter methylation of E-cadherin gene in gastric mucosa associated with Helicobacter pylori infection and in gastric cancer. Gut. 2003;52(4):502-6.

74. Chan AO-O, Wong BC-Y, Lan H-Y, Loke S-L, Chan W-K, Hui W$\mathrm{M}$, et al. Deregulation of E-cadherin-catenin complex in precancerous lesions of gastric adenocarcinoma. J Gastroenterol Hepatol. 2003;18(5):534-9.

75. Chan AOO, Peng JZ, Lam SK, Lai KC, Yuen MF, Cheung HKL, et al. Eradication of Helicobacter pylori infection reverses Ecadherin promoter hypermethylation. Gut. 2006;55(4):463-8.

76. Hamada K, Mikasa K, Yunou Y, Kurioka T, Majima T, Narita N, et al. Adjuvant effect of clarithromycin on chemotherapy for murine lung cancer. Chemotherapy. 2000;46(1):49-61.

77. Grünberger B, Hauff W, Lukas J, Wöhrer S, Zielinski CC, Streubel $\mathrm{B}$, et al. "Blind" antibiotic treatment targeting Chlamydia is not effective in patients with MALT lymphoma of the ocular adnexa. Ann Oncol. 2006;17(3):484-7. 